\title{
Evidence of use of road drainage culverts by Timon lepidus (Daudin, 1802) in Western Andalusia
}

Juan Domingo Delgado \& María de los Ángeles Gómez ${ }^{2}$

1 Área de Ecología, Dept. Sistemas Físicos, Químicos y Naturales, Univ. Pablo de Olavide, E-41013 Ctra. de Utrera Km.1, Sevilla, Spain.

\section{Resumen}

Correspondence

J.D. Delgado

E-mail: jddelgar@upo.es

Received: 15 January 2016

Accepted: 15 April 2016

Published on-line: 16 May 2016
Evidencia del uso de drenaje viario por Timon lepidus (Daudin, 1802) en Andalucía occidental

El uso de estructuras de drenaje viario y otros pasos inferiores potenciales para reptiles se encuentra escasamente estudiado. En esta nota presentamos una evidencia fotográfica de lagartos ocelados (Timon lepidus) usando un conducto estrecho lineal de drenaje bajo una carretera de tráfico intenso en Andalucía occidental (SeviIla). Nuestros datos sugieren que los lagartos podrían estar usando esta alternativa de desplazamiento contribuyendo a movimientos entre hábitats de esta especie amenazada, disminuyendo el riesgo de atropellos y mitigando los efectos de la fragmentación del hábitat.

Palabras clave: Lagartos, Lacertidae, Fragmentación viaria, Paso inferior, Permeabilidad viaria.

\begin{abstract}
Use of road drainage structures and other potential underpasses such as culverts by reptiles is scarcely studied. We present photographic evidence of Ocellated lizards (Timon lepidus) using a narrow, linear road drainage under an intense-traffic road in western Andalusia (Seville). Our finding suggests that lizards could benefit of using these alternative routes diminishing risks of road killing, and that even narrow culverts could be contributing to an inter-habitat displacement in this threatened lizard species by mitigating habitat fragmentation effects.
\end{abstract}

Key words: Lizards, Lacertidae, Road fragmentation, Underpass, Road permeability.

\section{Introduction}

The Ocellated lizard, Timon lepidus (Daudin, 1802), is a lacertid species of southwestern Europa (Near Threatened according to IUCN criteria; Pleguezuelos et al. 2009). This species is distributed mainly through Spain and Portugal, with localized populations in France and Italy (Bischoff et al. 1984, Mateo 2002, Salvidio et al. 2004, Grillet et al. 2010, Doré et al. 2011). Main declining causes of the species are habitat loss and fragmentation, including roads and traffic im- 
pacts, pesticides, poisoning, predator shifting to lizard prey, increase in generalist predator density, consumption by humans, and reduction of livestock grazing (Pleguezuelos et al. 2009, Mateo 2011).

Road-traffic mortality is one of the most important causes inducing lizard population reductions (Martínez-Rica 1981, Pleguezuelos et al. 2002, PMVC 2003). In this way, T. lepidus represented $5.4 \%$ of the killed reptiles (147 of 2714 ) and $35.4 \%$ of all killed lacertids, as recorded by a national-scale road-kill survey in Spain (PMVC 2003). Andalusia was the region with a higher incidence of kill records within Spain (22.4 $\%$; PMVC 2003). Most records of road-killed lizards were produced in spring-summer (peaking April to July; PMVC 2003). However, impact of traffic on this saurian could be overestimated due to its higher detectability along road surveys, compared with smaller lizards (PMVC 2003). Apart from mortality sinks for lizards, roads may act as barriers against dispersal (Forman et al. 2002). For this reason, the availability of refuges and passageways are a more critical factor conditioning distribution of T. lepidus than other mesohabitat traits such as vegetative cover, substrate type or even human presence (Doré et al. 2011, Mateo 2011).

Use of drainage culverts and other road underpasses by lizards of various species is scarcely studied. However, some authors have recorded such passage use by reptiles in the Iberian Peninsula, including lizards (Yanes et al. 1995, Rodríguez et al. 1996, Ascensão \&Mira 2007, Mata et al. 2008). Tellería et al. (2011) did not detect barrier effect on T. lepidus in a motorway crossing forest habitat in northern Spain. Yanes et al. (1995) found that intensity of passage use was higher in summer than in spring and autumn, and detected only two tracks of T. lepidus through culverts under transport corridors in Madrid, suggesting that culverts would allow safer passage for these reptiles.

Fourteen such potential underpasses were surveyed in May-June 2014 along the road A-376, between the kilometer points 12 and 17 (Seville province, SW Spain) (See underpass features in Appendix). The studied road is a four-lane motorway, ca. $37 \mathrm{~m}$ wide, with a service parallel dirt track alongside each asphalt verge. It maintains a traffic intensity of 17,170 vehicles/day (Ministerio de Fomento, 2014). Both sides of the motorway were fenced, although there were holes at irregular intervals, some of them coinciding with European rabbit trail routes.

We surveyed road culverts and other drainage and mixed-use structures that could be used as faunal conducts, with one unit of Döerr BolyGuard, 5.0 megapixel IR digital camera. The selected culverts had their mouths surrounded by concealing vegetation which aided to minimize removal by pedestrians and drivers. Only 2 culvert-type structures were a priori appropriate as placements for installation of the camera, due to high degree of exposition to pedestrians and vehicles of the remaining ones. We placed the camera at these 2 underpasses (coded \#4 and \#6, see Appendix) in different days, and set the camera at hours of lower human activity for discrete 24-h periods of operation.

In previous inspections of both structures, we incidentally detected signs of Ocellated lizard or other species at the entrance of underpass \#4 but none at underpass \#6. The camera was thus operated for only one 24-hour period at underpass \#6 and for six 24-hour periods (144 hours) at underpass \#4. In all, we obtained 11 photos (not showing any animal species) in underpass \#6 and 26 photos in underpass \#4, of which 14 photos showed animal use or presence at the underpass entrance.

In underpass \#4, 8 photos corresponded to rats (probably Rattus rattus L., 1758), clearly entering or emerging from the culvert; 1 to a House sparrow, Passer domesticus (L., 1758) at the entrance; and 5 photos showed presence of Ocellated lizard, two of them neatly emerging from the culvert mouth. The camera was stolen in subsequent days from another nearby location, and the photographic survey was thus interrupted.

The used culvert had the following traits: location UTM: 30S 246404 E, 41289 N; elevation: 65 $\mathrm{m}$; type of section of the structure: circular; diameter: $60 \mathrm{~cm}$; approximate length: $48 \mathrm{~m}$; material: concrete; linear shape: straight; visibility: both mouths visibly open and unconcealed by deposits or rubbish; fitted with a central air vent (median of the road); presence of outer lateral ledges; vegetation cover within $5 \mathrm{~m}$ of mouth: $60 \%$, composed of shrub and herbs; distance to asphalt road edge: $5 \mathrm{~m}$; road edge located at a height from passage mouth level of ca. $3.5 \mathrm{~m}$. 
The culvert used by Ocellated lizards in the A376 motorway was longer $(48 \mathrm{~m})$ and narrower $(0.6 \mathrm{~m})$ than those crossed by reptiles in another camera study in Madrid (average culvert length: $13.1 \mathrm{~m}$, diameter: $1.2 \mathrm{~m}$; Yanes et al. 1995). In fact, wider available culverts near from our culvert \#4 did not show consistent signs of lizard use. On the other hand, the structure crossed by lizards was also used by other animals. This could be indicating that other environmental and structural factors associated to both the culvert and immediate surroundings may determine selective use of the underpass by several species.

Other researchers have concluded that reptiles prefer crossing conducts of intermediate dimensions, as compared to small mammals which would use narrower underpasses (Rodríguez et al. 1996). Furthermore, the roof of the conduct was perforated at the center of the road corridor, in the median band, allowing light to reach the interior of the structure. This could mean more favorable conditions of temperature and light environment for lizard crossing.

The absence of detritus pits (that could act as biological traps for some species) at both ends of the culvert and the presence of vegetation and sandy-rocky ground nearby could be other favoring habitat features for vertebrate species using underpasses (Ascensão \& Mira 2007). No specifically-designed vertebrate crossing structures were found along the road A-376 in our study.
Hence, in roads of dense traffic and high risk of road killing, such common, narrow drainage structures may be frequently used as conducts under the asphalt corridor in lizard movement.

Our observations stress the idea that reptiles, especially lacertids, can effectively use this kind of draining conducts within their home ranges and probably also to disperse to new areas (see also Yanes et al. 1995). Large overpasses or wildlife crossing platforms would be perhaps more effective for reptiles and other local species because they provide a larger and quieter amount of habitat than culverts. However, other economic, landscape and legal (the studied road does not cross protected natural areas) prospects are to be considered for minimizing road barrier effects in this concrete sector. Provided this lizard species is vulnerable to mortality by traffic and road-traps, the inclusion of new specifically designed culverts and improvement of operating ones, in road projects in sensible zones, would be more affordable aiding measures for the conservation of this and other reptile species. If this is not just a casual phenomenon, our observations point to a possible use of drainage conducts which is relevant given the important negative effect of roads in this lizard species. In future studies it would be necessary to extend these surveys to other road underpasses, different seasons along a full annual cycle, and with a larger sampling intensity (i.e. increasing camera numbers).

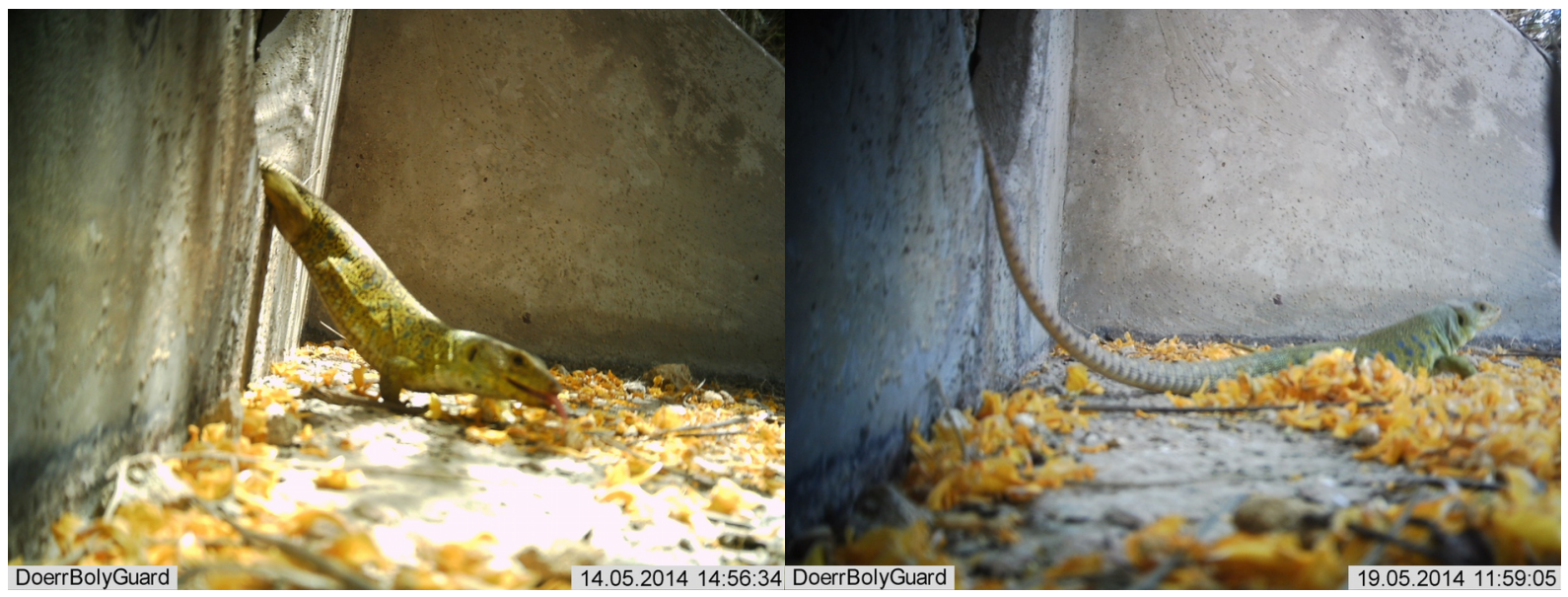

Figura 1. Capturas de cámara de dos adultos diferentes de lagarto ocelado en el paso inferior \#4, segmento de carretera 1; A) arriba: individuo \#1; 14/05/2014 (GMT: 14:56:34 h); B) abajo: individuo \#2; 19/05/2014 (GMT: 11:59:05 h).

Figure 1. Camera captures of two different adults of Ocellated lizard at underpass \# 4, road segment 1; A) above: individual \#1; 14/05/2014 (GMT: 14:56:34 h); B) below: individual \#2; 19/05/2014 (GMT: 11:59:05 h). 


\section{Acknowledgements}

We thank José Antonio Gómez for his help in the field work. This work was partially supported by grant "Ayuda p.p. 11.10, Grupos Emergentes" of the Universidad Pablo de Olavide, Seville, Spain, to the first author.

\section{References}

Ascensão F \& Mira A. 2007. Factors affecting culvert use by vertebrates along two stretches of road in southern Portugal. Ecological Research 22: 57-66.

Bischoff W, Cheylan M \& Böhme W. 1984. Lacerta lepida Daudin 1802. Pp. 181-210 in: Böhme, W. (ed.): Handbuch der Reptilien und Amphibien Europas, Aula-Verlag, Wiesbaden.

Díaz-Ruiz F \& Ferreras P. 2011. Depredación de Timon lepidus por gato asilvestrado. Boletín de la Asociación Herpetológica Española 22: 148-151.

Doré F, Grillet $\mathrm{P}$, Thirion JM, Besnard A \& Cheylan M. 2011. Implementation of a long-term monitoring program of the ocellated lizard (Timon lepidus) population on Oleron Island. Amphibia-Reptilia 32:159-166.

Forman RTT, Sperling D, Bissonette JA, Clevenger AP, Cutshall CD, Dale VH, Fahrig L, France R, Goldman CR, Heanue K, Jones JA, Swanson FJ, Turrentine T \& Winter TC. 2003. Road Ecology: Science and Solutions. Island Press, Washington, D.C.

Grillet $P$, Cheylan M, Thirion JM, Doré F, Bonnet X, Dauge C, Chollet S \& Marchand MA. 2010. Rabbit burrows or artificial refuges are a critical habitat component for the threatened lizard, Timon lepidus (Sauria, Lacertidae). Biodiversity Conservation 19: 2039-2051.

Martínez-Rica JP. 1981. Nota sobre la protección de especies amenazadas de anfibios y reptiles en España. Pirineos 114: 75-86.

Mata C, Hervás I, Herranz J, Suárez F \& Malo JE. 2008. Are motorway wildlife passages worth building? Vertebrate use of road-crossing structures on a Spanish motorway. Journal of Environmental Management
88: 407-415.

Mateo JA. 2002. Lacerta lepida Daudin, 1802. Lagarto ocelado. Pp. 225-227 in: Pleguezuelos, J. M., R. Márquez, and M. Lizana (eds.): Atlas y libro Rojo de los Anfibios y Reptiles de España. Dirección General de Conservación de la Naturaleza, Asociación Herpetológica Española, Madrid.

Mateo JA. 2011. Lagarto ocelado - Timon lepidus. En: Enciclopedia Virtual de los Vertebrados Españoles. Salvador, A., Marco, A. (Eds.). Museo Nacional de Ciencias Naturales, Madrid. Available in http://www. vertebradosibericos.org.

Ministerio de Fomento. 2014. Mapas provinciales de tráfico. Sevilla. Secretaría de Estado de Infraestructuras, Transporte y Vivienda, Secretaría General de Infraestructuras, Dirección General de Carreteras, Gobierno de España. Available in http://www.fomento.gob.es /Carreteras/MapProvin2014.pdf (accesed on 15-III-2016).

Pleguezuelos JM, Márquez R \& Lizana M (eds.) 2002. Atlas y Libro Rojo de los Anfibios y Reptiles de España. Dirección General de Conservación de la Naturaleza-Asociación Herpetológica Española (2a impresión), Madrid, 587 pp.

Pleguezuelos JM, Sá-Sousa P, Pérez-Mellado V, Márquez R, Cheylan M, Corti C \& Martínez-Solano í. 2009. Timon lepidus. The IUCN Red List of Threatened Species. Version 2014.3. Available in www.iucnredlist.org (accesed on 26-III-2015).

PMVC. 2003. Mortalidad de vertebrados en carreteras. Documento técnico de conservación $n^{\circ} 4$. Sociedad para la Conservación de los Vertebrados (SCV). Madrid, $350 \mathrm{pp}$.

Salvidio S, Lamagni L, Bombi P \& Bologna MA. 2004. Distribution, ecology and conservation status of the ocellated lizard (Timon lepidus) in Italy (Reptilia, Lacertidae). Italian Journal of Zoology 71: 125-134.

Tellería JL, Díaz JA, Pérez-Tris J, De Juana E, De La Hera I, Iraeta P, Salvador A \& Santos T. 2011. Barrier effects on vertebrate distribution caused by a motorway crossing through fragmented forest landscape. Animal Biodiversity and Conservation 34: 331-340.

Yanes, M, Velasco JM \& Suárez F. 1995. Permeability of roads and railways to vertebrates: The importance of culverts. Biological Conservation 71: 217-222. 


\section{Appendix}

Features of the studied underpasses in the road A-376 (Seville province, Spain).

The viaduct dimensions are shown as width and height. $\varnothing=$ Diameter (tubular structures or culverts). Max imum vegetation cover estimated within a radius of $5 \mathrm{~m}$ around one accessible mouth of the pass. All dimensions are in meters.

\begin{tabular}{|c|c|c|c|c|c|c|c|}
\hline Underpass & Type & Dimensions & Air vent & Light inside & Water & Distance of mouth to road & Habitat type \\
\hline 1 & Culvert & $\varnothing 0.60$ & Yes & Yes & No & 3 & Industrial-rural \\
\hline 2 & Culvert & $\varnothing 0.60$ & Yes & Yes & Yes & 4 & Agricultural \\
\hline 3 & Culvert & $\varnothing 1.80$ & No & Yes & No & 5 & Agricultural \\
\hline 4 & Culvert & $\varnothing 0.6$ & Yes & Yes & Yes & 5 & Agricultural \\
\hline 5 & Culvert & $\varnothing 1.80$ & No & Yes & No & 5 & Agricultural \\
\hline 6 & Culvert & $\varnothing 0.6$ & Yes & Yes & Yes & 4 & Agricultural \\
\hline 7 & Culvert & $\varnothing 1.80$ & No & Yes & No & 5 & Agricultural \\
\hline 8 & Culvert & $\varnothing 1.80$ & Yes & Yes & Yes & 6 & Agricultural \\
\hline 9 & Viaduct & $19.0 \times 4.25$ & Yes & Yes & Yes & 1 & Agricultural \\
\hline 10 & Culvert & $\varnothing 1.80$ & Yes & Yes & Yes & 1 & Agricultural \\
\hline 11 & Culvert & $\varnothing 0.60$ & Yes & Yes & Yes & 3 & Agricultural \\
\hline 12 & Culvert & $\varnothing 1.80$ & Yes & Yes & Yes & 5 & Agricultural \\
\hline 13 & Culvert & $\varnothing 1.80$ & Yes & Yes & Yes & 4 & Agricultural \\
\hline 14 & Culvert & $\varnothing 1.80$ & Yes & Yes & Yes & 2 & Industrial-rural \\
\hline
\end{tabular}

